\title{
THE DEPENDENCE OF NORMAL AND BLACK LIGHT TYPE TRAPPING RESULTS UPON THE WINGSPAN OF MOTH SPECIES
}

\author{
NOWINSZKY, L. ${ }^{1}{ }^{*}$ - PUSKÁs, J. ${ }^{1}-$ TAR, K. ${ }^{2}$ - HUFNAGEL, L. ${ }^{3}$ - LADÁNYI, M. ${ }^{3}$ \\ ${ }^{1}$ University of West-Hungary Savaria University Centre \\ H-9701 Szombathely Károlyi G. Square 4. \\ E-mail:Inowinszky@gmail.com; pjanos@gmail.com \\ ${ }^{2}$ University College of Nyíregyháza \\ Institute of Tourism and Science of Geography \\ H-4400 Nyíregyháza Sóstói Str. 31/B \\ E-mail:tarko47@gmail.com \\ ${ }^{3}$ Corvinus University of Budapest \\ Dpt. of Biometrics and Agricultural Informatics \\ H-1118 Budapest, Villányi út 29-43. \\ E-mail:marta.ladanyi@uni-corvinus.hu; leventehufnagel@gmail.com \\ *Corresponding author \\ e-mail: lnowinszky@gmail.com \\ (Received $4^{\text {th }}$ September 2013; accepted $28^{\text {th }}$ October 2013)
}

\begin{abstract}
In the last decade several researchers found relation between the wingspan size of moths and their light sensitivity. Generally, moths with larger wingspan have higher light sensitivity. We tested these findings using the catch data of 378 Macrolepidoptera species from 19 black light (BL, $125 \mathrm{~W}$ ) and normal light trap $(100 \mathrm{~W})$ pairs of the Hungarian Light Trap Network. We have found that wingspan size of about $25 \mathrm{~mm}$ is the limit below which some species were trapped more effectively by normal light trap, compared to BL. However, BL trap catch ratio of moths with wingspan of over about $35 \mathrm{~mm}$ is nearly $100 \%$, compared to normal light trap. According to the catch results of a site where normal and BL traps were placed close enough for the moths to perceive both at the same time, $75 \%$ of moths with even small wingspan were caught by BL traps. Regarding the fact that BL traps collected significantly more individuals of Macrolepidoptera species with their wingspan over $35 \mathrm{~mm}$ on all sites of observation, we can conclude that Wolfram light bulb of $100 \mathrm{~W}$ is hardly suitable to use for this purpose. Consequently, considering our results, the light trap type can more effectively be specialized to the purpose of the observation according to the wingspan of the targeted species from which fact plant protection applications and entomological research projects can successfully benefit.
\end{abstract}

Keywords: Macrolepidoptera, wingspan, spectral sensitivity, light traps

\section{Introduction}

For a long time, researchers have been investigating the catch results of light traps with different light sources and the spectral sensitivity of insects' eye.

A given type of light source determines, among others, the temperature, the colour temperature and the spectral distribution of the light energy it emits. Electroretinogram measurements are used to determine the spectral sensitivity of the insects' eye. In the literature, several studies are devoted to the results of laboratory measurements carried out on various species. No reports of such experiments are known in Hungary and data on the most important Hungarian pestilent species are also missing from the international literature of the subject. 


\section{Review of literature}

Mikkola (1972) established that moths and butterflies (Lepidoptera) and caddisfly species (Trichoptera) have an eye sensitivity that remains practically unchanged in the spectrum of $350-600 \mathrm{~nm}$. Its maximum is around $550 \mathrm{~nm}$ (as the value of human eye during daytime). The sensitivity is mightily reduced at about $620 \mathrm{~nm}$.

McFarlane and Eaton (1973) have reported that the responses of Cabbage Looper (Trichoplusia $n i \mathrm{Hbn}$.) to monochromatic light stimuli have been investigated by electroretinogram (ERG) and electromyogram (EMG) techniques. The spectral sensitivity curves for male and female Cabbage Loppers show a major peak at 540 to $550 \mathrm{~nm}$ and a minor peak at $360 \mathrm{~nm}$.

Agee (1973) showed by elektroretinogram test that the sensitivity of eyes of the Bollworm Moth (Heliothis zea Boddie) and Tobbacco Bollworm (Heliothis virescens F.) to $365 \mathrm{~nm}$ and $480-575 \mathrm{~nm}$ wavelengths light is highest.

Pappas and Eaton (1977) found that the ocelli of the Tobacco Hornworm (Manduca sexta L.) are more sensitive to $520 \mathrm{~nm}$ light, than to $360 \mathrm{~nm}$ light stimuli.

Similar results are reported by Eguchi et al. (1982) about the Sphingid moths. These moths possess the highest peak sensitivity at $540 \mathrm{~nm}$.

Gui et al. (1942) reported that the colours on which comparable data are available arrange themselves in order from least to most attractive to insects, as follows: red, yellow, white and blue.

From tests of Taylor and Deay (1950) it appears that the maximum attractiveness for the European corn borer (Ostrinia nubilalis Hbn.) is in the near ultraviolet region between 320 and $380 \mathrm{~nm}$.

Frost (1954) had a comparative experiment. He found that for all taxa of insects the black light was more attractive than the white light. The only exceptions were the Miridae and Chrysopidae families, which preferred white light.

Cleve (1954) found a strikingly successful ultraviolet fluorescent lamp to collect the insects, if it illuminated a white sheet.

Belton and Kempster (1963) caught more noctuid moths (Noctuidae) and geometrid ones (Geometridae) with the black light (BL) fluorescent tube than with the cold light $(\mathrm{CW})$.

Jászainé (1964) analyzed the catching results of Common Meadow Bug (Exolygus pratensis Wagner) (Heteroptera: Miridae) in normal and BL light traps. The standard light traps caught more individuals.

In the comparative studies of Mészáros (1966), each of the Microlepidoptera species were more effectively collected by the BL traps than by normal light ones.

In the test of Day and Reid (1969) the $15 \mathrm{~W}$ fluorescent BL lamps were more attractive for the Conoderus falli Lane (Coleoptera: Elateridae) than similar yellow ones.

According to the experiment of Komlódi (1970) the standard light trap caught only a few specimens of the Eurasian Hemp Moths (Grapholita delineana Walker), a lamp operating with HgLS light source, however, caught numerous of these moths. Wingspan of the Eurasian Hemp Moths is 10-14 mm.

Sifter (1971) examined the swarming of the Chestnut Weevil (Curculio elephas Gyllenhal, Coleoptera: Curculionidae) by normal and BL traps. The body length of this beetle is only 6-9 mm. The normal light trap has not caught a single specimen, but the $\mathrm{BL}$ one was suitable for investigation of swarming. 
Mikkola (1972) verified the results of his laboratory measurements with the help of light trap monitoring. He caught the highest number of insects with lamps emitting both black light and visible light. The catch dwindled when he used BL alone and visible light produced even poorer result.

Striking contradiction was found between light sensitivity and the attracting effect of different types of light, regarding six insect groups (Coleoptera, Trichoptera, Lepidoptera, Brachycera, and Nematocera Ichneumonoidea). The eyes of these insects were more sensitive to yellow light than to BL, but the attracting effect was the opposite.

Blomberg et al. (1976) compared two types of light trap catch results. One of them was the so-called blended light trap that contained a $160 \mathrm{~W}$ Tungsram mercury fluorescent lamp and the other one was BL that was provided with a $125 \mathrm{~W}$ Philips HPW lamp. The mercury fluorescent lamp caught approximately twice as many moths of the Macrolepidoptera families (Geometridae and Noctuidae) and Microlepidoptera species than the BL trap.

According to laboratory tests of Teel et al. (1976) the maximum sensitivity of the eye of Hickory Shuckworm (Laspeyresia caryana Fitch) is at $365 \mathrm{~nm}$ and $515 \mathrm{~nm}$. At these two values, there were six times as many individuals responding to the near-ultraviolet light than ones responding to the green one.

According to Gál et al. (1976), Bürgés and Gál (1981) and Bürgés (1997) for the light trapping of the Chestnut Weevil (Curculio elephas Gyllenhal) and the Acorn Moth (Cydia splendana $\mathrm{Hbn}$.) the most effective tool is the mercury vapour lamp $(\mathrm{HgW})$.

Some observers report that there are species showing a greater attraction to regular light: some fruit flies (Theowald, 1963), virus vector cicadae (Laodelphax striatella (Fallén)) and Javesella pellucida (Fabricius) (Homoptera, Areopidae) (Jászainé, 1969); European Grapevine Moth (Lobesia botrana Den. et Schiff.) and Vine Moth (Eupoecilia ambiguella Hbn.) (Voigt and Vojnits, 1970).

Extremely valuable conclusions come from a series of experiments by Járfás et al. (1975) and Járfás and Tóth (1977) in which comparisons were made among the catch results yielded by $125 \mathrm{~W}$ (HgVE 27) ultraviolet, $125 \mathrm{~W}$ (HgLSE27) mercury vapour, 100 W (OHP 220-230 VAO) crypton, 100W (F F $_{3}$ 50cm neon, 250W (E 279043 IMP) infra ruby and $50 \mathrm{~cm}$ germicidal lamps. Silver Y moths (Autographa gamma L.), Pine Chafers (Polyphylla fullo L.), Vine Chafers (Anomala vitis Fabr.) and Scarab Beetles (Anoxia orientalis Kryniczky) flew to the mercury vapour lamps in the highest numbers, while infra ruby light proved to be practically unsuitable for trapping. Járfás $(1975,1977)$ published the results of his experiments, in which he examined the efficiency of light traps with respect to different moth species with the application of different lightsources. The most suitable traps for catching were the following, in descending order: mercury lamp $(\mathrm{HgW}), \mathrm{BL}$ and normal light, in the case of the following species: Silver Y (Autographa gamma L.) (Járfás et al., 1975), the Codling Moth (Cydia pomonella L.) (Járfás et al. 1977), the Pea Podborer (Etiella zinckenella Tr.) (Járfás and Viola, 1984) and the Beet Webworm (Loxostege sticticalis L.) (Járfás and Viola, 1991). Járfás (1977) reports that the Apple Peel Tortrix (Adoxophyes reticulana Hbn.), the Pear Moth (Laspeyresia pyrivora Pan.) and the Plum Fruit Moth (Grapholita funebrana Tr) can be caught effectively with the mercury vapour lamp $(\mathrm{HgW})$, the Strawberry Tortricid (Pandemis dumetana Tr.) and the Dark Fruit-tree Tortrix (Pandemis heparana Den. et Schiff.) are more attracted to a normal light bulb. The European Corn Borer (Ostrinia 
nubilalis $\mathrm{Hbn}$.) was collected by the $\mathrm{HgW}$ traps more successfully than by the normal and the BL traps (Járfás, 1978).

Skuhravý et al. (1993) found a BL trap much more effective than either yellow, green or red lights in collecting the Saddle Gall Midge (Haplodiplosis marginata von Roser) (Diptera: Cecidomydae).

In our earlier study (Nowinszky and Puskás, 1994), we compared the composition of species of five Macrolepidoptera families based on the normal and BL trap data collected at two light trap stations, by the Sorensen index. The results are as follows: Geometridae: 0.607 and 0.518; Sphingidae: 0.750 and 0.500; Notodontidae: 0.444 and 0.429; Arctiidae: 0.714 and 0.609; Noctuidae: 0.608 and 0.527 .

Wallner et al. (1995) carried out experiments of three lymantriid species in the Russian Far East. There were significantly more moths in the fluorescent black light lamp than either in the phosphor mercury or the high-pressure sodium lamps, in case of all three species: Gipsy Moth (Lymantria dispar L.), Nun Moth (Lymantria monaca L.) and the Pink Gipsy Moth (Lymantria matura Moore).

Nabli et al. (1999) studied the efficiency of catching agriculturally benficial insects by using different light sources. The Coccinellidae (Coleoptera) species preferred BL, the Ophion sp. (Hymenoptera: Ichneumonidae) had a preference for blue BL. Chrysopa spp. (Neuroptera: Chrysopidae) could be trapped equally well with white and BL, while every source of light had the same impact on some broad damsel bugs (Hemiptera: Nabidae) and Hemerobius spp. (Neuroptera: Hemerobiidae).

Bürgés et al. (2003) found the following characteristics of those families (Geometridae, Sphingidae, Notodontidae, Arctiidae and Noctuidae) that are rich in species: most of their species fly to both normal and BL traps, but the BL one catches significantly more species. The number of specimen caught was also less in the normal light trap.

Fayle et al. (2007) examined three Robinson type light traps equipped with $125 \mathrm{~W}$ mercury bulbs. One of these contained materials which absorb the visible light, so this lamp was a BL type trap. Their results showed that the least moth was caught by the BL trap.

Barghini (2008) tested four lighting systems. Most insects were caught in the highpressure mercury lamp $(\mathrm{Hg})$. A further order was as follows: high-pressure sodium $(\mathrm{Na})$ without a BL filter and the same type with BL filter.

In the last decade most researchers found connection between body size of the insects (larger eyes or wingspan) and their light sensitivity. Insects with larger eyes and wingspan tend to have higher light sensitivity than those with smaller eyes. Over the last decade, published studies supported the finding that the vision of insects with greater body weight is more sensitive to light than that of the smaller species. Such a statement was published concerning desert ants (Cataglyphis) (Zollikofer et al. 1995); pollen foraging bees (Apoidea) (Jander and Jander, 2002); the bumblebees (Bombus terrestris L.) (Spaethe and Chittka, 2003) and Kapustjanskij et al. 2007); the nymphalid butterflies (Nymphalidae) (Rutowski et al. 2009).

Moser et al. (2004) found a connection between the size of eyes of 10 Atta species (Hymenoptera: Formicidae) and the time of nuptial flight using digital photography. The diameter of compound eyes of the night flying species was significantly larger.

Yack et al. (2007) reported similar results concerning the Macrosoma eliconiaria Walker (Lepidoptera: Hedyloidea) species. 
Experiments of Kino and Oshima (1978) suggest that moth and butterfly emanations could cause allergy-induced bronchial asthma in certain people. Since moths are readily attracted to artificial light and often fly into houses, these insects are especially suspected as important factors in extrinsic asthma.

Barghini and Medeiros (2010) assumed that in developing countries the growing light pollution will affect the spread of vector-borne human diseases.

Van Langevelde et al. (2011) established that moths are attracted to artificial light with smaller wavelength in higher species richness and abundance than to light with larger wavelength. This attraction was correlated with the body mass, wingspan and eye size of moths. The size dependent attraction of the artificial light sources cause distortions to the ecosystems.

In the above mentioned studies the catch coming from parallelly operated regular and black light (BL) traps offered a unique possibility to answer the following questions.

- Is there a significant difference in species and families between the catch yielded by the two types of traps?

- Which of the two types is more suitable for trapping what species?

- Are there any species that can be collected by either regular or BL traps alone?

- Does either of the two types indicate the presence of more species than the other?

- To what extent do the materials yielded by the two types of trap at the same observation site differ in their composition by species?

In the present study we examined how the wingspan of Macrolepidoptera species can influence the catch result of normal light traps and BL ones based on data from the Hungarian Light Trap Network.

\section{Material}

To compare the differences between the practical use of normal and BL traps the Hungarian Plant Protection Research Institute of Keszthely has been carrying out experiments since 1962 with parallel operation of two light trap types, one with a regular bulb and the other with BL. In 1962 the Plant Protection Service added a BL trap in Nagytétény to the ones running with regular light and in 1963 equipped all its county plant protection stations with BL traps. The national network of normal and BL traps operated in parallel opened up the possibility to a comprehensive analysis of the catch results.

The normal and BL traps operated in the following cities and villages:

\begin{tabular}{l|l}
\hline Baj (47.38N, 18.21E) & Mikepércs $(47.26 \mathrm{~N}, 21.37 \mathrm{E})$ \\
Csopak $(45.58 \mathrm{~N}, 17.55 \mathrm{E})$ & Miskolc $(48.5 \mathrm{~N}, 20.46 \mathrm{E})$ \\
Fácánkert $(46.26 \mathrm{~N}, 18.44 \mathrm{E})$ & Nagytétény $(47.38 \mathrm{~N}, 18.97 \mathrm{E})$ \\
Gyöngyös $(47.46 \mathrm{~N}, 19.55)$ & Pacsa $(46.43 \mathrm{~N}, 17.0 \mathrm{E})$ \\
Györ-Kismegyer $(47.39 \mathrm{~N}, 17.39 \mathrm{E})$ & Szederkény $(45.59 \mathrm{~N}, 18.27 \mathrm{E})$ \\
Hódmezóvásárhely (46.25N, 20.19E) & Tanakajd (47.11N, 16.44E) \\
Kaposvár (46.22N, 17.46) & Tarhos (46.48N, 21.12E) \\
Kállósemjén $(47.51 \mathrm{~N}, 21.55)$ & Tass $(47.1 \mathrm{~N}, 19.2 \mathrm{E})$ \\
Kenderes $(47.13 \mathrm{~N}, 20.45 \mathrm{E})$ & Velence $(47.14 \mathrm{~N}, 18.38 \mathrm{E})$ \\
Keszthely $(46.46 \mathrm{~N}, 17.15 \mathrm{E})$ & \\
\hline
\end{tabular}


The most valuable information was provided by the light traps at Nagytétény where, according to the station register entries, regular and BL traps were placed at a mere 10 metres distance from one another. The proximity of the two traps meant homogeneity of microclimate, vegetation and the distances from the habitats of other species and so the insects were practically offered the choice of two different light sources.

The complete Macrolepidoptera material of the above listed light traps was processed in our work. We processed the data of 378 species of the data of the 18 light trap sites belonging to the National Network and the data of 222 species collected by the light traps of Nagytétény.

The data of the wingspan of the different Macrolepidoptera species we collected from the websites of "Moths of Hungary" József Szalkai Hungarian Lepidopterist Association (www.macrolepidoptera.hu) and UK moths (www.ukmoths.org.uk).

\section{Methods}

We summarized in each light trap site and each trap type the number of the Macrolepidoptera species and individuals caught from all generations, however, we did not separate the individuals within generations. Then, using the Mann-Whitney's test we checked the significance of the homogeneity of the number of individuals captured by normal and BL traps, separately for all species and recorded significantly $(\mathrm{p}<0.05)$ higher normal trap or BL trap catches marked as $\mathrm{N}$ or BL, respectively, while insignificant differences were marked as E (Table 1). Particular attention was paid to the data of Nagytétény's normal and BL traps, since the two trap types were set close enough to represent homogeneous microclimate, vegetation and species habitat ranges so the moths were supposed to be able to choose directly between different light sources.

We arranged all the species collected both by the national light trap network (NW) and by the Nagytétény (NT) traps in ascending order according to the wingspan sizes of insects. We calculated the percentages of species caught significantly more effectively by the black light traps (BL) and normal ones (N) and the percentages of the species caught insignificantly differently by the two types of traps $(E)$ where the percentages were taken over the sum of all catches, separately for the data of National Light Trap Network (NW) and Nagytétény (NT).

The differences between the $\mathrm{BL}$ and $\mathrm{N}$ dominated results together with insignificantly different results for the species observed both in NW and NT sites were tested familywise by Z-tests at the 0.05 level (Moore et al. 2006).

For NW and NT results, separately, we compared the proportions BL, N and E familywise by Marascuillo's test at the 0.05 level (National Institute of Standards and Technololgy, 2010).

As a next step, we pooled the species of all families into one data set and ordered them by their average wingspan.

First, splitting the total range of the observed wingspan sizes into categories, we took the ratio BL over BL+N and compared these by Marascuillo's test.

Then, using the ordered, pooled data set, the moving averages with a window size of 7 days were calculated for BL, N and E proportions of the observations of NW and NT. 
To represent the wingspan dependency of the BL, N and E proportions, we defined a joint regression model containing models of three subranges of the following formula:

$$
Y=\chi\left[X<s_{1}\right] * Y_{1}+\chi\left[s_{1} \leq X<s_{2}\right] * Y_{2}+\chi\left[X \geq s_{2}\right] * Y_{3}+\varepsilon
$$

where $Y_{1}, Y_{2}$ and $Y_{3}$ are functions of the general formulas:

$$
\begin{gathered}
Y_{1}=p_{11}+p_{12} *\left(1-\exp \left(-p_{13} *(32-X)\right)\right) \\
Y_{2}=p_{21}+\left(p_{22}-p_{21}\right) /\left(1+\exp \left(-p_{23} *\left(X-p_{24}\right)\right)\right) \\
Y_{3}=p_{31}+p_{32} *\left(1-\exp \left(-p_{33} *\left(X-p_{34}\right)\right)\right)
\end{gathered}
$$

In the formulas $Y$ denotes the moving average of the percentages of $\mathrm{BL}, \mathrm{N}$ and $\mathrm{E}$ with window size 7 while $X$ is for the wingspan size $(\mathrm{mm})$ and $\varepsilon$ is a normally distributed error term with expected value of zero;

$S_{1}$ and $s_{2}$ are wingspan values $(\mathrm{mm})$ that indicate the borders of the wingspan subranges;

$\chi\left[X<s_{1}\right], \chi\left[s_{1} \leq X<s_{2}\right] \chi\left[X \geq s_{2}\right]$ are characteristic functions which take 1 if the conditions given in brackets $\left[X<s_{1}\right],\left[s_{1} \leq X<s_{2}\right]_{\text {or }}\left[X \geq s_{2}\right]$ hold and zero else;

$p_{i j}$ are the parameters of the functions $Y_{i}(i=1,2,3, j=1,2,3,4)$.

$\mathrm{Y}_{1}$ and $\mathrm{Y}_{3}$ are saturation functions with the following properties:

- $Y_{1}(32)=p_{11} ; Y_{3}\left(p_{34}\right)=p_{31}$;

- The decrease of $Y_{1}$ and $Y_{3}$ from their values $p_{11}$ or $p_{31}$ are $p_{12}$ or $p_{32}$ as $X \rightarrow+\infty$, respectively. Obviously, if $p_{12}>0$ then $\mathrm{Y}_{1}$ is decreasing, otherwise it is increasing and if $p_{32}>0$ then $Y_{3}$ is decreasing, otherwise it is increasing.

- $p_{13}>0$ and $p_{33}>0$ are the a velocity factors of the exponential term of $\mathrm{Y}_{1}$ and $Y_{3}$, respectively.

$\mathrm{Y}_{2}$ is a logostic function with the following properties:

- $p_{21}$ is the limit $Y_{2}$ approaches as $X \rightarrow-\infty$;

- $p_{22}$ is the limit $Y_{2}$ approaches as $X \rightarrow+\infty$;

- $p_{23}>0$ is a velocity factor of the exponential term of $Y_{2}$;

- $p_{24}$ is the inflexion point of $Y_{2}$.

Normality of the error terms was tested by Shapiro-Wilk's test ( $p>0.05)$. Parameter estimations were calculated together with their t-values and significance levels. The regression models were tested by their F-values and their significance levels. Finally, the explained variances $\left(\mathrm{R}^{2}\right)$ were evaluated. 


\section{Results and discussion}

Table 1 summarizes the average wingspan data $(\mathrm{mm})$ of all the 378 trapped species sorted into families and presents the numbers of species that were collected significantly more effectively by the normal $(\mathrm{N})$ or black light (BL) traps of the Hungarian Light Trap Network (Network) and, separately, of Nagytétény. The significant differences are based on Mann-Whitney's test at the $\mathrm{p}<0.05$ level.

Comparing the normal light trap dominated proportions of Macrolepidoptera species of the National Light Trap Network sites and Nagytétény (Table 2) by Z-tests, we detected no significant differences $(\mathrm{p}>0.05)$. The BL dominated results of Geometridae, Arctiidae and Noctuidae catches, however, were significantly higher in Nagytétény ( $\mathrm{p}<0.001)$ where the potential chance for the species to choose between the two types of trap was higher.

Table 1. Numbers and average wingspan $(\mathrm{mm})$ of Macrolepidoptera species collected significantly more effectively by normal $(N)$ or black light $(B L)$ traps of the Hungarian Light Trap Network (Network) and, separately, of Nagytétény. The significant differences are based on Mann-Whitney's test at the $p<0.05$ level

\begin{tabular}{|c|c|c|c|c|c|c|c|c|}
\hline \multirow{3}{*}{ Family name } & \multirow{3}{*}{$\begin{array}{c}\text { Average } \\
\text { wingspan } \\
(\mathrm{mm})\end{array}$} & \multicolumn{4}{|c|}{ Network } & \multicolumn{3}{|c|}{ Nagytétény } \\
\hline & & \multirow[t]{2}{*}{$\begin{array}{l}\text { No. of } \\
\text { different } \\
\text { species } \\
\text { caught }\end{array}$} & \multirow[t]{2}{*}{$\begin{array}{l}\text { No. of } \\
\text { trap } \\
\text { pairs }\end{array}$} & \multicolumn{2}{|c|}{$\begin{array}{c}\text { No. of different } \\
\text { species caught } \\
\text { significantly } \\
\text { more by }\end{array}$} & \multirow[t]{2}{*}{$\begin{array}{l}\text { No. of } \\
\text { different } \\
\text { species } \\
\text { caught }\end{array}$} & \multicolumn{2}{|c|}{$\begin{array}{c}\text { No. of different } \\
\text { species caught } \\
\text { significantly } \\
\text { more by }\end{array}$} \\
\hline & & & & $N$ & $B L$ & & $N$ & $B L$ \\
\hline Nolidae & 19.0 & 2 & 12 & 0 & 0 & 0 & 0 & 0 \\
\hline Syntominae & 23.0 & 1 & 12 & 0 & 0 & 0 & 0 & 0 \\
\hline Geometridae & 26.1 & 104 & 1122 & 17 & 7 & 58 & 13 & 38 \\
\hline Drepanidae & 28.2 & 5 & 45 & 0 & 0 & 1 & 0 & 0 \\
\hline Thaumetopoidae & 30.0 & 1 & 8 & 0 & 1 & 1 & 0 & 1 \\
\hline Noctuidae & 34.4 & 194 & 2248 & 4 & 85 & 126 & 7 & 105 \\
\hline Arctiidae & 34.5 & 22 & 267 & 0 & 6 & 15 & 1 & 12 \\
\hline Thyatiridae & 37.3 & 3 & 16 & 0 & 1 & 0 & 0 & 0 \\
\hline Lymantriidae & 38.8 & 7 & 65 & 0 & 2 & 3 & 0 & 2 \\
\hline Notodontidae & 39.7 & 19 & 203 & 2 & 8 & 10 & 2 & 8 \\
\hline Lasiocampidae & 42.2 & 8 & 85 & 0 & 3 & 2 & 0 & 1 \\
\hline Sphingidae & 73.3 & 11 & 153 & 0 & 9 & 6 & 1 & 4 \\
\hline Saturniidae & 82.5 & 2 & 12 & 0 & 2 & 0 & 0 & 0 \\
\hline
\end{tabular}

Moreover, comparing those proportions of species the catches of which were significantly higher neither for the normal nor the BL light trap type (E) in Nagytétény or in other sites of the National Light Trap Network, we found that in Nagytétény these numbers were significantly lower $(\mathrm{p}<0.001)$ for Geometridae, Arctiidae and Noctuidae families. These significant differences indicate that in case the species of Geometridae, Arctiidae and Noctuidae families can choose between the two light trap types, they prefer the BL type traps, while, in case the potential possibility of choice is low, then the trapping success of the two types of light traps is homogeneous. 
Table 2. Numbers of Macrolepidoptera species observed both in Network sites (NW) and Nagytéteny (NT) with the numbers of species collected significantly more effectively by normal $(N)$ or black light $(B L)$ traps, or, insignificantly differently by the two types of traps $(E)$ of the Hungarian Light Trap Network (NW) and, separately, Nagytétény (NT). The significant differences in boldface are based on Z-tests at the $p<0.05$ level

\begin{tabular}{|c|c|c|c|c|c|c|c|}
\hline \multirow[t]{3}{*}{ Family name } & \multirow[t]{3}{*}{$\begin{array}{c}\text { Number of } \\
\text { species observed } \\
\text { both in NW and } \\
N T\end{array}$} & \multirow{2}{*}{\multicolumn{2}{|c|}{$\begin{array}{c}\text { Numbers of } \\
\text { species collected } \\
\text { insignificantly } \\
\text { differently by } B L \\
\text { and } N \\
E\end{array}$}} & \multicolumn{4}{|c|}{$\begin{array}{l}\text { Numbers of species collected } \\
\text { significantly more effectively by }\end{array}$} \\
\hline & & & & \multicolumn{2}{|c|}{$B L$} & \multicolumn{2}{|c|}{$N$} \\
\hline & & $N W$ & $N T$ & $N W$ & $N T$ & $N W$ & $N T$ \\
\hline Lasiocampidae & 2 & 1 & 1 & 1 & 1 & 0 & 0 \\
\hline Drepanidae & 1 & 1 & 1 & 0 & 0 & 0 & 0 \\
\hline Geometridae & 58 & $44 * * *$ & 7 & 2 & $38 * * *$ & 17 & 13 \\
\hline Sphingidae & 6 & 0 & 1 & 6 & 5 & 0 & 0 \\
\hline Notodontidae & 10 & $3^{+}$ & $\mathbf{0}$ & 5 & 8 & 2 & 2 \\
\hline Thaumetopoidae & 1 & 1 & 0 & 0 & 1 & 0 & 0 \\
\hline Lymantriidae & 3 & 1 & 1 & 2 & 2 & 0 & 0 \\
\hline Arctiidae & 15 & $10 * * *$ & 2 & 5 & $12 * * *$ & 0 & 1 \\
\hline Noctuidae & 126 & $57 * * *$ & 14 & 47 & $105 * * *$ & 2 & $7^{+}$ \\
\hline
\end{tabular}

+significant at the $\mathrm{p}<0.1$ level; $* * *$ significant at the $\mathrm{p}<0.001$ level; proportions are compared by Z-test

Table 3. Numbers of Macrolepidoptera species collected significantly more effectively by normal $(N)$ or black light $(B L)$ traps, or, insignificantly differently by the two types of traps $(E)$ of the Hungarian Light Trap Network (NW). The three proportions are compared, different letters are for significantly different proportions based on Marascuillo's test at the $p<0.05$ level

\begin{tabular}{|c|c|c|c|c|}
\hline \multirow[t]{2}{*}{ Family } & \multirow{2}{*}{$\begin{array}{c}\text { Average } \\
\text { wingspan } \\
\text { (mm) }\end{array}$} & \multirow{2}{*}{$\begin{array}{c}\begin{array}{c}\text { Numbers of species collected } \\
\text { insignificantly differently by BL and } N\end{array} \\
E\end{array}$} & \multicolumn{2}{|c|}{$\begin{array}{l}\text { Numbers of species } \\
\text { collected significantly } \\
\text { more effectively by }\end{array}$} \\
\hline & & & $B L$ & $N$ \\
\hline Nolidae & 19.0 & 2 2 b & $0 \mathrm{a}$ & $0 \mathrm{a}$ \\
\hline Syntominae & 23.0 & $1 \mathrm{~b}$ & $0 \mathrm{a}$ & $0 \mathrm{a}$ \\
\hline Geometridae & 26.1 & $80 \mathrm{~b}$ & $7 \mathrm{a}$ & $17 \mathrm{a}$ \\
\hline Drepanidae & 28.2 & $5 \mathrm{~b}$ & $0 \mathrm{a}$ & $0 \mathrm{a}$ \\
\hline Thaumetopoidae & 30.0 & $0 \mathrm{a}$ & $1 \mathbf{b}$ & $1 a b$ \\
\hline Noctuidae & 34.4 & $105 \mathrm{~b}$ & $85 \mathrm{~b}$ & $4 \mathrm{a}$ \\
\hline Arctiidae & 34.5 & $16 \mathrm{~b}$ & $6 \mathrm{a}$ & $0 \mathrm{a}$ \\
\hline Thyatiridae & 37.3 & $2 \mathrm{a}$ & $1 \mathrm{a}$ & $0 \mathrm{a}$ \\
\hline Lymantriidae & 38.8 & $5 \mathrm{~b}$ & $2 a b$ & $0 \mathrm{a}$ \\
\hline Notodontidae & 39.7 & $9 \mathrm{a}$ & $8 \mathrm{a}$ & $2 \mathrm{a}$ \\
\hline Lasiocampidae & 42.2 & $5 \mathrm{~b}$ & $3 a b$ & $0 \mathrm{a}$ \\
\hline Sphingidae & 73.3 & $2 \mathrm{a}$ & $9 \mathrm{~b}$ & $0 \mathrm{a}$ \\
\hline Saturnidae & 82.5 & $0 \mathrm{a}$ & $2 \mathrm{~b}$ & $0 \mathrm{a}$ \\
\hline
\end{tabular}

When we compared the proportions of Macrolepidoptera species collected significantly more effectively by normal (N) or black light (BL) traps, or, insignificantly differently by the two types of traps (E) of the Hungarian Light Trap Network (NW) by Marascuillo's test (Table 3), we saw that for families of smaller wingspan sizes (Nolidae, Syntominae, Geometridae, Drepanidae), the trapping success is typically rather homogeneous for the two trap types (E) while for families of greater wingspan 
sizes (Lasiocampidae, Sphingidae, Saturnidae), the BL trap types are significantly more preferred $(\mathrm{p}<0.05)$.

Performing the same comparisons for the proportions recorded in Nagytétény (Table 4 ), we could state that independently from the wing size, the preference of the species is the BL type of trap. However, none of the families includes species that could be captivated by only one type of traps.

Table 4. Numbers of Macrolepidoptera species collected significantly more effectively by normal $(N)$ or black light $(B L)$ traps, or, insignificantly differently by the two types of traps $(E)$ in Nagytétény (NT). Different letters are for significantly different proportions based on Marascuillo's test at the $p<0.05$ level

\begin{tabular}{|c|c|c|c|c|}
\hline \multirow[t]{2}{*}{ Family } & \multirow{2}{*}{$\begin{array}{c}\text { Average } \\
\text { wingspan } \\
(\mathrm{mm})\end{array}$} & \multirow{2}{*}{$\begin{array}{c}\begin{array}{c}\text { Numbers of species collected } \\
\text { insignificantly differently by BL and } N\end{array} \\
E\end{array}$} & \multicolumn{2}{|c|}{$\begin{array}{l}\text { Numbers of species } \\
\text { collected significantly } \\
\text { more effectively by }\end{array}$} \\
\hline & & & $B L$ & $N$ \\
\hline Geometridae & 26.1 & $7 \mathrm{a}$ & 38 b & $13 \mathrm{a}$ \\
\hline Drepanidae & 28.2 & $1 \mathrm{~b}$ & $0 \mathrm{a}$ & $0 \mathrm{a}$ \\
\hline Thaumetopoidae & 30.0 & $0 \mathrm{a}$ & $1 \mathrm{~b}$ & $0 \mathrm{a}$ \\
\hline Noctuidae & 34.4 & $14 \mathrm{a}$ & $105 \mathrm{~b}$ & $7 \mathrm{a}$ \\
\hline Arctiidae & 34.5 & $2 \mathrm{a}$ & $12 \mathrm{~b}$ & $1 \mathrm{a}$ \\
\hline Lymantriidae & 38.8 & $1 \mathrm{a}$ & $2 \mathrm{a}$ & $0 \mathrm{a}$ \\
\hline Notodontidae & 39.7 & $0 \mathrm{a}$ & $8 \mathrm{~b}$ & $2 \mathrm{a}$ \\
\hline Lasiocampidae & 42.2 & $1 \mathrm{~b}$ & $1 \mathrm{~b}$ & $0 \mathrm{a}$ \\
\hline Sphingidae & 73.3 & $1 \mathrm{a}$ & $4 \mathrm{~b}$ & $1 \mathrm{a}$ \\
\hline
\end{tabular}

The results of the Marascuillo's tests for the BL/(BL+N) ratios calculated from the results of the Hungarian Light Trap Network for wingspan range categories (Table 5) show that above a wingspan of about $30 \mathrm{~mm}$ the preference of BL traps becomes obvious.

Table 5. Numbers of Macrolepidoptera species collected significantly more effectively by normal (N) or black light (BL) traps of the Hungarian Light Trap Network (NW) with the BL ratio over $(B L+N)$. The multiple ratios were compared, different letters indicate significantly different ratios based on Marascuillo's test at the $p<0.05$ level

\begin{tabular}{c|c|c|c|c}
\hline $\begin{array}{c}\text { Wingspan } \\
\text { range } \\
(\boldsymbol{m m})\end{array}$ & $\begin{array}{c}\text { Average wingspan } \\
(\boldsymbol{m m})\end{array}$ & \multicolumn{2}{|c|}{$\begin{array}{c}\text { Numbers of species collected } \\
\text { significantly more effectively by }\end{array}$} & \multirow{2}{*}{$\boldsymbol{B L} /(\boldsymbol{B L}+\boldsymbol{N})$ ratio } \\
\cline { 3 - 4 } & 19.48 & $\boldsymbol{B}$ & $\boldsymbol{N}$ & \\
\hline $11-23$ & 26.07 & 9 & 10 & $0.29 \mathrm{a}$ \\
$24-28$ & 30.17 & 11 & 7 & $0.56 \mathrm{ab}$ \\
$29-31$ & 32.85 & 22 & 1 & $0.79 \mathrm{ab}$ \\
$32-34$ & 35.39 & 11 & 1 & $0.96 \mathrm{~b}$ \\
$35-36$ & 38.15 & 22 & 0 & $0.92 \mathrm{~b}$ \\
$37-40$ & 42.57 & 15 & 1 & $1.00 \mathrm{~b}$ \\
$41-45$ & 47.00 & 9 & 0 & $1.94 \mathrm{~b}$ \\
$46-48$ & 51.46 & 10 & 0 & $1.00 \mathrm{~b}$ \\
$49-57$ & 84.18 & 10 & 0 & $1.00 \mathrm{~b}$ \\
$58-115$ & & &
\end{tabular}


Performing the same comparisons for the $\mathrm{BL} /(\mathrm{BL}+\mathrm{N})$ ratios recorded in Nagytétény (Table 6) we can conclude that the preference of BL type traps is independent from the wingspan size.

Considering the above results together with this, we can state that normal type light traps can be at most as successful as BL type traps, independently from the wingspan size. Over the wingspan of about $35 \mathrm{~mm}$ the $\mathrm{BL} /(\mathrm{BL}+\mathrm{N})$ ratio is nearly 100 percent in all sites except for in Nagytétény, where the normal and the BL traps were close enough for moths to be able to choose between them, the $\mathrm{BL} /(\mathrm{BL}+\mathrm{N})$ ratios of the species with even the smallest wingspan were over $75 \%$.

Table 6. Numbers of Macrolepidoptera species collected significantly more effectively by normal $(N)$ or black light $(B L)$ traps in Nagytétény $(N T)$ with the BL ratio over $(B L+N)$. The multiple ratios were compared, no significantl differences were detected by Marascuillo's test at the $p<0.05$ level

\begin{tabular}{c|c|c|c|c}
\hline $\begin{array}{c}\text { Wingspan } \\
\text { range } \\
(\boldsymbol{m m})\end{array}$ & $\begin{array}{c}\text { Average wingspan } \\
(\boldsymbol{m m})\end{array}$ & \multicolumn{2}{|c|}{$\begin{array}{c}\text { Numbers of species collected } \\
\text { significantly more effectively by }\end{array}$} & \multirow{2}{*}{$\boldsymbol{B} \boldsymbol{L} /(\boldsymbol{B} \boldsymbol{L}+\boldsymbol{N})$ ratio } \\
\cline { 3 - 4 } & & $\boldsymbol{B L}$ & $\boldsymbol{N}$ & \\
\hline $11-23$ & 19.48 & 24 & 6 & 0.75 \\
$24-28$ & 26.07 & 21 & 1 & 0.78 \\
$29-29$ & 29.00 & 7 & 2 & 0.88 \\
$30-35$ & 32.51 & 50 & 2 & 0.96 \\
$36-40$ & 37.74 & 31 & 2 & 0.94 \\
$41-44$ & 42.07 & 15 & 1 & 0.88 \\
$45-48$ & 46.29 & 5 & 1 & 0.83 \\
$49-57$ & 51.46 & 5 & & 0.83 \\
\hline
\end{tabular}

The results of the regression joint model optimized for the BL, N and E proportions are summarized in Table 7 for the Hungarian light Trap Network data and in Table 8 for the data recorded in Nagytétény (see Eq.1 to Eq.4). The observed total wingspan range was split into three subranges cutted by $s_{1}=32$ and $s_{2}=36$ (Figure 1, black vertical lines or $s_{2}=39$ (Figure 1, blue vertical line) in case of the Hungarian Light Trap Network data and by $s_{1}=33$ and $s_{2}=40$ (Figure 2, black vertical lines) in case of the data recorded in Nagytétény.

\section{Subrange 1}

In the wingspan subrange below $32 \mathrm{~mm}$ (Network) or $33 \mathrm{~mm}$ (Nagytétény) the $\mathrm{N}$ and E proportions can be modelled by decreasing exponential (i.e. saturation) functions (Eq.2). The BL proportions can be modelled by increasing exponential (i.e. saturation) functions (Eq.2). In case of $\mathrm{N}$ proportions the functions of the Network and Nagytétény observations are very similar. In case of BL proportions, however, the values of Network model are much lower than the ones of Nagytétény while in case of $\mathrm{E}$ proportions the relation is reverse: the values of Network model are much higher than the ones of Nagytétény. Moreover, some species of wingspan size below $25 \mathrm{~mm}$ were trapped more effectively by normal light trap, compared to BL. 


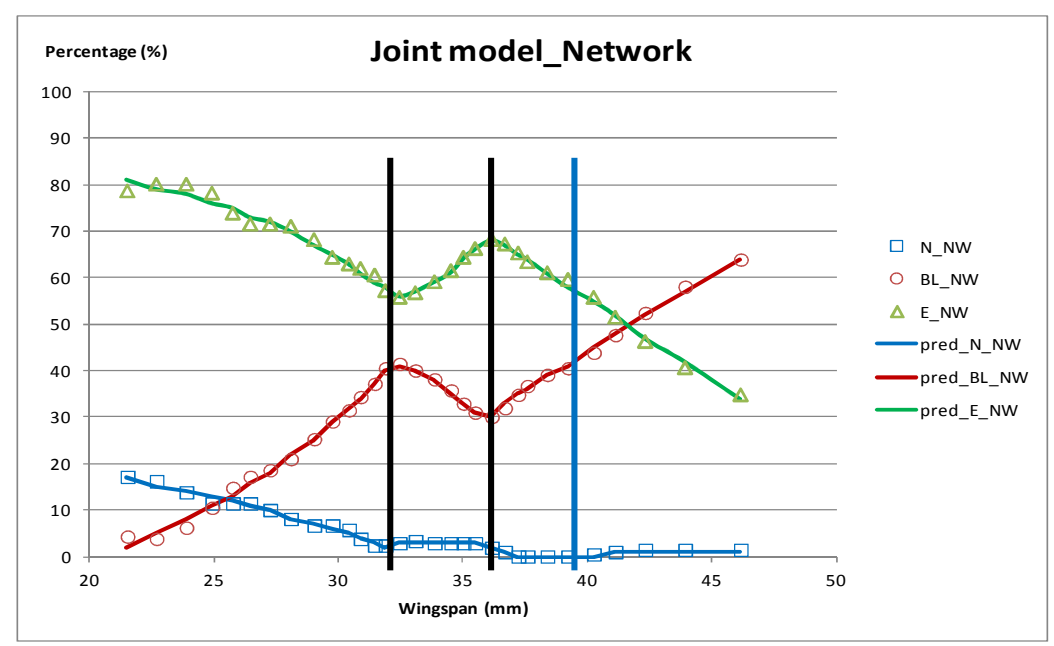

Figure 1. Proportions of the numbers of Macrolepidoptera species collected significantly more effectively by normal $(N)$ or black light $(B L)$ traps or, insignificantly differently by the two types of traps $(E)$ of the Hungarian Light Trap Network $(N W)$ and their joint models containing the models of three subranges. The vertical lines represent the borders of the wingspan subranges (see also Table 7)

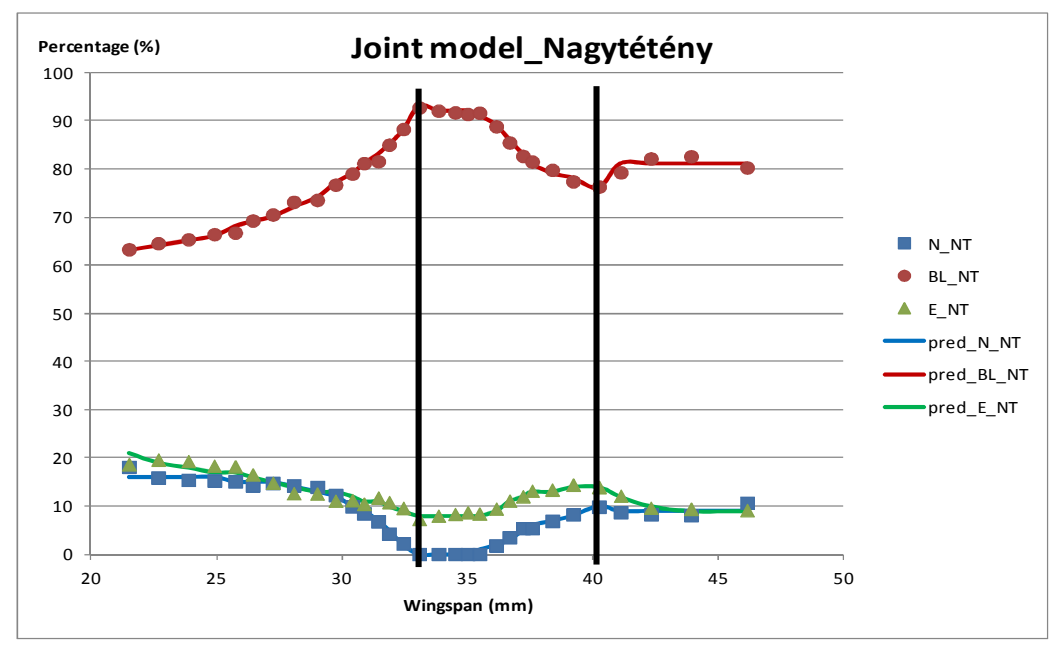

Figure 2. Proportions of the numbers of Macrolepidoptera species collected significantly more effectively by normal $(N)$ or black light $(B L)$ traps or, insignificantly differently by the two types of traps $(E)$ in Nagytétény $(N T)$ and their joint models containing the models of three subranges.

The vertical lines represent the borders of the wingspan subranges (see also Table 8)

\section{Subrange 2}

The catch results of species of wingspan in Subrange 2 refer to a different trend of attraction of the moths and this surprisingly modified trend were detected both for the data of Network and Nagytétény.

In the wingspan subrange above $32 \mathrm{~mm}$ (Network) or $33 \mathrm{~mm}$ (Nagytétény) and below $36 \mathrm{~mm}$ (Network) or $40 \mathrm{~mm}$ (Nagytétény) the E proportions can be modelled by increasing, the BL proportions by decreasing logistic functions (Eq.3). The values of $\mathrm{E}$ proportions are much higher in case of Network data while the BL proportions are higher in Nagytétény. 
In the wingspan subrange above $32 \mathrm{~mm}$ (Network) or $33 \mathrm{~mm}$ (Nagytétény) and below $39 \mathrm{~mm}$ (Network) or $40 \mathrm{~mm}$ (Nagytétény) the $\mathrm{N}$ proportions can be modelled by logistic functions (Eq.3) differently for the data of Network and Nagytétény. The first is decreasing while the second one is increasing; nevertheless, the values of both functions are very small.

Table 7. Results of the regression joint model optimized for the $B L, N$ and E proportions of the Hungarian Light Trap Network: parameter estimations with their t-values and significance levels, the F-values of the models and their significance levels as well as the explained variances $\left(R^{2}\right)$ with their significance levels

\begin{tabular}{|c|c|c|c|c|c|c|c|c|c|c|c|}
\hline & \multicolumn{3}{|c|}{$\begin{array}{l}\text { Subrange 1 } \\
\chi[X<32]\end{array}$} & \multicolumn{3}{|c|}{$\begin{array}{c}\text { Subrange 2 } \\
\chi[32 \leq X<36]\end{array}$} & \multicolumn{3}{|c|}{$\begin{array}{l}\text { Subrange 3 } \\
\chi[X \geq 36]\end{array}$} & \multicolumn{2}{|c|}{ Joint Model } \\
\hline & \multicolumn{2}{|c|}{\begin{tabular}{|c|}
$\begin{array}{c}\text { Estimated } \\
\text { parameters }\end{array}$ \\
\end{tabular}} & \multirow{2}{*}{$\begin{array}{c}\boldsymbol{t} \\
6278 * * *\end{array}$} & \multicolumn{2}{|c|}{$\begin{array}{c}\text { Estimated } \\
\text { parameters }\end{array}$} & \multirow{2}{*}{\begin{tabular}{|c|}
$\boldsymbol{t}$ \\
$23.82 * * *$
\end{tabular}} & \multicolumn{2}{|c|}{$\begin{array}{c}\text { Estimated } \\
\text { parameters }\end{array}$} & \multirow{2}{*}{$\begin{array}{c}\boldsymbol{t} \\
93.33 * * *\end{array}$} & $F$ & $R^{2}$ \\
\hline \multirow{4}{*}{ E } & $p_{11}$ & 0.57 & & $p_{21}$ & 0.56 & & $p_{31}$ & 0.66 & & & \\
\hline & $p_{12}$ & 0.32 & $7.57 * * *$ & $p_{22}$ & 0.70 & $13.31 * * *$ & $p_{32}$ & -6.32 & 0.21 n.s. & 8023.60 & $0.99 * * *$ \\
\hline & $p_{13}$ & 0.13 & $3.76 * * *$ & $p_{23}$ & 1.28 & $2.38 * * *$ & $p_{33}$ & 0.01 & 0.20 n.s. & & \\
\hline & & & & $p_{24}$ & 34.82 & $65.08 * * *$ & $p_{34}$ & 37.00 & fixed & & \\
\hline \multirow{6}{*}{$\mathrm{N}$} & \multicolumn{3}{|c|}{$\begin{array}{l}\text { Subrange 1 } \\
\chi[X<32],\end{array}$} & \multicolumn{3}{|c|}{$\begin{array}{c}\text { Subrange 2 } \\
\chi[32 \leq X<39]\end{array}$} & \multicolumn{3}{|c|}{$\begin{array}{l}\text { Subrange 3 } \\
\chi[X \geq 39]\end{array}$} & \multicolumn{2}{|c|}{ Joint Model } \\
\hline & \multicolumn{2}{|c|}{\begin{tabular}{|c|} 
Estimated \\
parameters
\end{tabular}} & $t$ & \multicolumn{2}{|c|}{$\begin{array}{c}\text { Estimated } \\
\text { parameters }\end{array}$} & $t$ & \multicolumn{2}{|c|}{$\begin{array}{c}\text { Estimated } \\
\text { parameters }\end{array}$} & $t$ & $F$ & $R^{2}$ \\
\hline & $p_{11}$ & 0.02 & $5.12 * * *$ & $p_{21}$ & 0.03 & $10.81 * * *$ & $p_{31}$ & -0.36 & 0.00 n.s. & \multirow{4}{*}{$376.17 * * *$} & \multirow{4}{*}{$0.99 * * *$} \\
\hline & \multirow{3}{*}{$p_{13}$} & 0.41 & $1.98^{+}$ & $p_{22}$ & 0.00 & fixed & $p_{32}$ & 0.05 & $4.22 * * *$ & & \\
\hline & & 0.04 & 1.59 n.s. & $p_{23}$ & 3.22 & $9.75 * * *$ & $p_{33}$ & 7.03 & $5.27 * * *$ & & \\
\hline & & & & $p_{24}$ & 36.40 & $\begin{array}{c}146.56 \\
* * *\end{array}$ & $p_{34}$ & 40.00 & & & \\
\hline \multirow{6}{*}{ BL } & \multicolumn{3}{|c|}{$\begin{array}{l}\text { Subrange 1 } \\
\chi[X<32],\end{array}$} & \multicolumn{3}{|c|}{$\begin{array}{c}\text { Subrange 2 } \\
\chi[32 \leq X<36]\end{array}$} & \multicolumn{3}{|c|}{$\begin{array}{l}\text { Subrange } 3 \\
\chi[X \geq 36]\end{array}$} & \multicolumn{2}{|c|}{ Joint Model } \\
\hline & \multicolumn{2}{|c|}{\begin{tabular}{|c|} 
Estimated \\
parameters
\end{tabular}} & $t$ & \multicolumn{2}{|c|}{$\begin{array}{l}\text { Estimated } \\
\text { parameters }\end{array}$} & $t$ & \multicolumn{2}{|c|}{$\begin{array}{l}\text { Estimated } \\
\text { parameters }\end{array}$} & $t$ & $F$ & $R^{2}$ \\
\hline & \multirow{4}{*}{$\mathrm{L} \mid p_{12}$} & 0.40 & $57.10 * * *$ & $p_{21}$ & 0.41 & $28.10 * * *$ & $p_{31}$ & 0.34 & $59.72 * * *$ & & \\
\hline & & -0.60 & $9.34 * * *$ & $p_{22}$ & 0.29 & $12.01 * * *$ & $p_{32}$ & 7.77 & 0.19 n.s. & 3749.06 & 0.007 \\
\hline & & 0.10 & $5.62 * * *$ & $p_{23}$ & 1.54 & $1.97^{+}$ & $p_{33}$ & 0.004 & 0.19 n.s. & & 0.991 \\
\hline & & & & $p_{24}$ & 34.61 & $\begin{array}{c}117.93 \\
* * *\end{array}$ & $p_{34}$ & 37.00 & fixed & & \\
\hline
\end{tabular}

+ significant at the $\mathrm{p}<0.1$ level; * significant at the $\mathrm{p}<0.05$ level

$* *$ significant at the $\mathrm{p}<0.01$ level; *** significant at the $\mathrm{p}<0.001$ level 
Table 8. Results of the regression joint model optimized for the BL, $N$ and E proportions recorded in Nagytetény: parameter estimations with their t-values and significance levels, the $F$-values of the models and their significance levels as well as the explained variances $\left(R^{2}\right)$ with their significance levels

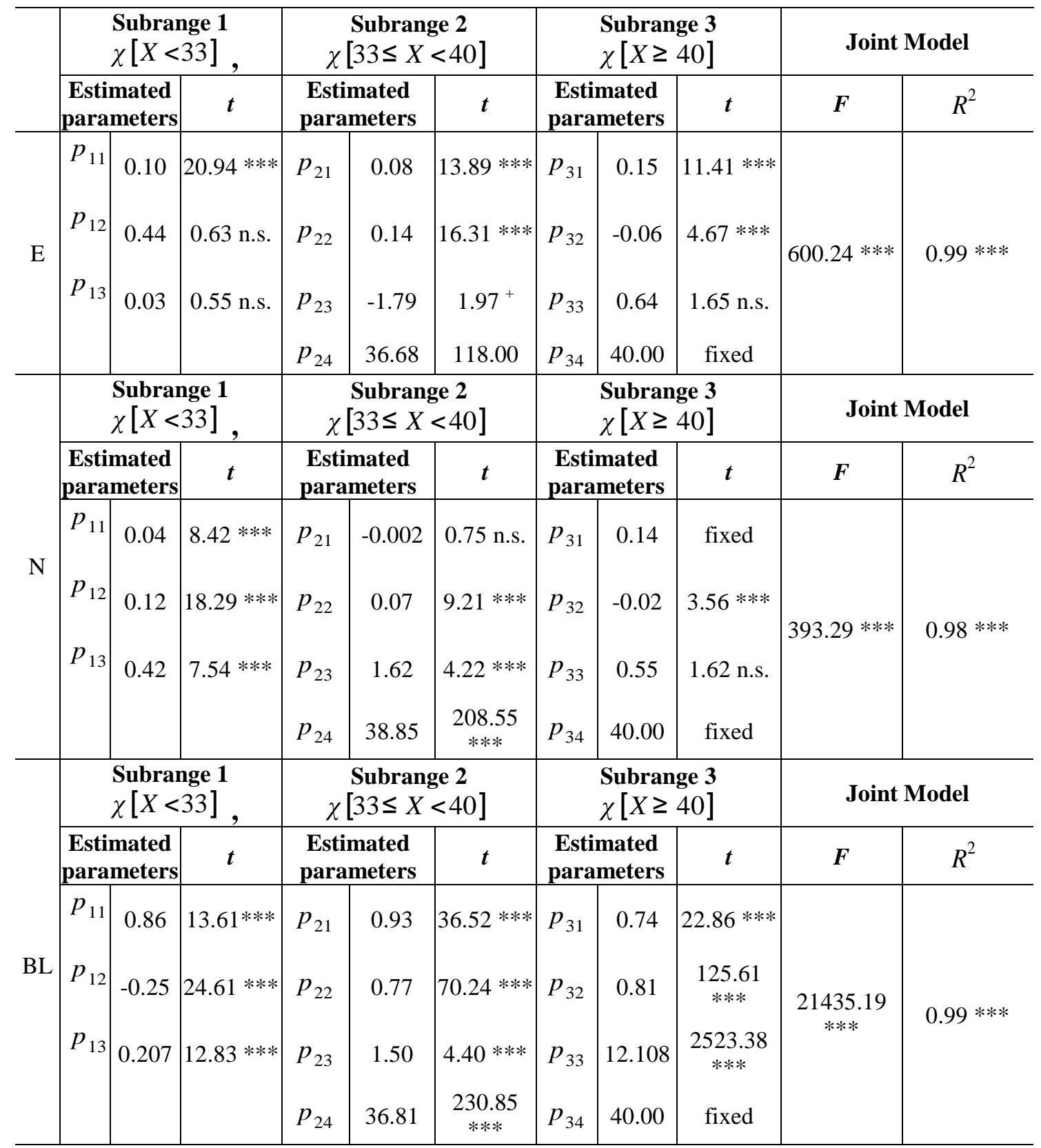

+ significant at the $\mathrm{p}<0.1$ level; $*$ significant at the $\mathrm{p}<0.05$ level

** significant at the $\mathrm{p}<0.01$ level; *** significant at the $\mathrm{p}<0.001$ level

\section{Subrange 3}

In the wingspan subrange above $36 \mathrm{~mm}$ (Network) or $40 \mathrm{~mm}$ (Nagytétény) the $\mathrm{E}$ proportions can be modelled by decreasing, the BL proportions by increasing exponential (i.e. saturation) functions (Eq.4). The values of E proportions are much higher in case of Network data while the BL proportions are higher in Nagytétény. 
In the wingspan subrange above $39 \mathrm{~mm}$ (Network) or $40 \mathrm{~mm}$ (Nagytétény) the $\mathrm{N}$ proportions can be modelled by exponential (i.e. saturation) functions (Eq.4) differently for the data of Network and Nagytétény. The first is increasing while the second one is decreasing; nevertheless, the values of both functions are very small.

These characteristics of the models correspond to the results of the comparisons of proportions (Z-tests and Marascuillo's tests) and can be reasoned by the fact that in Nagytétény the preference of the species can be more effectively observed and it is definitely BL, especially for the species of wingspan sizes above $39-40 \mathrm{~mm}$.

When the normal and BL type traps were very close to each other, the BL traps were chosen by even the moths of small wingspans en masse. However, occasionally, such choices are suspected to be random and the proof of the preferences desires more observations.

We stress that the fact that the preference of the species of large wingspans is unambiguously BL does not mean that these species cannot be collected with a normal light trap successfully. We only state that the preference of BL type traps is significant and thus the Wolfram light bulb of $100 \mathrm{~W}$ is less effective.

When choosing a suitable light trap type for a special aim, the harmful effects of light traps should also be considered. Kollings (2000) has established that there is a definite difference in the composition of the catch from two neighbouring street lamps of different types. Our results coincide with the observations of Kolling as we also confirmed that the different light sources can damage different species and to different degrees. In an experiment by Eisenbei and Hassel (2000), the use of natrium vapour street lamps reduced the number of insects caught by 50\%, including a $75 \%$ reduction in the number of moths. According to Frank (2006), if some moth species are more attracted to light than others, the traits related to this attraction could help us to predict effects of artificial light on communities of nocturnal species. Since the artificial light sources of different wavelengths attract different species to different degrees, thus this effect on the community can distract the balance of a local ecosystem.

Our results can be applied in plant protection and entomological research projects when the aim is to find the most effective type of light traps for special purposes and different targeted species. Before a responsible decision, the type and rate of damage risk, the targeted species with their wingspan sizes and also environmental aspects should be deliberately considered.

\section{REFERENCES}

[1] Agee, H.R. (1973): Spectral sensitivity of the compound eyes of field-collected adult bollworms and tobacco budworms. - Annals of the Entomological Society of America 66: 613-615.

[2] Barghini, A. (2008): Influência da Illuminãçao Artificial sobre a Vida Silvestre: técnicas para minimizar os impactos, com especial enfoque sobre os insectos. - Universidade de São Paolo, Instituto de Biosciências, Programa de Pós-Graduãçao em Ecologia. 229 pp.

[3] Barghini, A., Medeiros, B.A.S. (2010): Artificial Lighting as a vector attractant and cause of disease diffusion. - Environmental Health Perspectives 118: 1503-1506.

[4] Belton, P., Kempster, R.H. (1963): Some factors affecting the catches of Lepidoptera in light traps. - The Canadian Entomologist 95(2): 832-837.

[5] Blomberg, O., Itämies, J., Kuusela, K. (1976): Insect catch in a blended and a black light trap in northern Finland. - Oikos 27: 57-63. 
[6] Bürgés, Gy. (1997): Light trap catch depending on the power, colour and height of the light sources (in Hungarian). - ${ }^{\text {4th }}$ Hungarian Ecological Congress, Pécs, 43.

[7] Bürgés, Gy., Gál, T. (1981): Zur Verbreitung und Lebensweise des Kastanienrüßlers (Curculio elephas Gyll., Col.: Curculionidae) in Ungarn. - Zeitschrift für angewandte Entomologie 91(4): 375-382.

[8] Bürgés, Gy., Nowinszky, L., Puskás, J., Herczig, B. (2003): Comparative study of Macrolepidoptera caught in light trap operating with normal and UV light. $-55^{\text {th }}$ International Symposium on Crop Protection. Ghent. Abstracts 140.

[9] Cleve, K. (1954). Einfluß der Wellenlänge des Lichtes auf den Lichtfang der Schmetterlinge. - In: Titschak, E. (eds.): Deutscher Entomologentag in Hamburg 30(3): 107-113. Jena (Fischer).

[10] Day, A., Reid, W.J. (1969): Response of adult Southern Potato Wireworms to light traps. - Journal of Economic Entomology 62(2): 314-318.

[11] Eguchi, E., Watanabe, K., Hariyama, T., Yamamoto, K. (1982): A comparison of electrophysiologically determined spectral responses in 35 species of Lepidoptera. Journal of Insect Physiology 28(8): 675-682.

[12] Eisenbeis, G., Hassel, F. (2000): Attraction of nocturnal insects to street lights - a study of municipal lighting systems in a rural area of Rheinhessen (Germany). - Natur und Landschaft 75(4): 145-156.

[13] Fayle, T.M., Sharp, R.E. Majerus, M.E.N. (2007): The effect of moth trap type on catch size and composition in British Lepidoptera. - Br. J. Ent. Nat. Hist. 20: 221-232.

[14] Frost, S.W. (1954): Response of insects to black and white light. - Journal of Economic Entomology 47(2): 275-279.

[15] Gál, T., Bürgés, Gy., Eke, I. (1976): Observation on the seasonal flight period of chestnut pests: a comparison of methods (in Hungarian). - 23. Növényvédelmi Tudományos Napok, Budapest, 203-211.

[16] Gui, H.L., Porter, L.C., Prideaux, G.F. (1942): Response of insects to color, intensity, and distribution of light. - Agricultural Engineering 23: 51-58.

[17] Hajtman, B. (1971): Introduction to mathematical statistics for psychologists (in Hungarian). - Akadémiai Kiadó, Budapest.

[18] Jander, U., Jander, R. (2002): Allometry and resolution of bee eyes (Apoidea). Arthropod Structure \& Development 30(3): 179-193.

[19] Járfás, J. (1977): Results of light trapping of harmful tortricid moths (in Hungarian). Kertészeti Egyetem Közleményei 41: 123-126.

[20] Járfás, J. (1978): The effictivity of different light trapping methods in studying the flight activity of European corn borer (in Hungarian). - Növényvédelem, 494-498.

[21] Járfás, J., Szabó, E., Ladics, L. (1977): Prediction of Codling Moth (Cydia pomonella L.) and the investigation of climatic factors modifying its swarming (in Hungary). Scientific Session of the Performances of "János Lippay" 2396-2419.

[22] Járfás, J., Szabó, E., Sohajda, I. (1975): Evaluation of meteorological factors influencing the signalization of Silver Y (Autorgapha gamma L.) based on light trap (in Hungarian). - Kertészeti Egyetem Közleményei 29: 167-174.

[23] Járfás, J., Tóth, J. (1977): Forecast and protection of the damaging Melolontha species in vineyard (in Hungarian). - Szőlőtermesztési Agrokémiai Tájékoztató, Kecskemét 3(1): 27.

[24] Járfás, J., Viola, M. (1984): Experience gained in the light trap observation of the Pea Podborer (Etiella zinckenella Treitschke) (in Hungarian). - A Kertészeti Egyetem Közleményei, 221-227.

[25] Járfás, J., Viola, M. (1991): The results of the observations of special light traps for Beet Webworm (Loxostege sticticalis L.) (in Hungarian). - Kertgazdaság 4: 65-70.

[26] Jászainé, V.E. (1964): Miridae species (Heteroptera) in the material of normal and blacklight traps of Hungarian light trap network in 1963 (in Hungarian). - Fol. Ent. Hung. 17: 471-524. 
[27] Jászainé, V.E. (1969): The swarming and distribution in Hungary of the cicadas spreading viruses Laodelphax striatella (Fallén) and Javesella pellucida (Fabricius, Homoptera, Areopidae) on the basis of the data of the national-wide light trap network (in Hungarian). Növényvédelem 5(1): 7-15.

[28] Kapustjanskij, A., Streinzer, M., Paulus, H.F., Spaethe, J. (2007): Bigger is better: implications of body size for flight ability under different light conditions and the evolution of alloethism in bumblebees. - Functional Ecology 21: 1130-1136.

[29] Kino, T., Oshima, Sh. (1978): Allergy to insects in Japan I. The reaginic sensitivity to moth and butterfly in patients with bronchial asthma. - Journal of Allergy and Clinical Immonology 61(1): 10-16.

[30] Kollings, D. (2000): Ecological effects of artificial light sources on nocturnally active insects, in particular on butterflies (Lepidoptera). - Faunistisch-Oekologische Mitteilungen Supplement 28: 1-136.

[31] Komlódi, J. (1970): Biology of the Eurasian Hemp Moth (Grapholita delineata Walker) and results of control experiments (in Hungarian). - Növényvédelem 6(8): 343-348.

[32] Manczel, J. (1983): Statistical methods in agriculture. - Mezőgazdasági Kiadó, Budapest, $496 \mathrm{pp}$.

[33] McFarlane, J.H., Eaton, J.L. (1973): Comparison of electroretinogram and electromyogram responses to radiant energy stimulation in the moth, Trichoplusia ni. Journal of Insect Physiology 19(4): 811-822.

[34] Mészáros, Z. (1966): A comparison of the Microlepidoptera materials collected by normal and UV light traps (in Hungarian). - Folia Entomologica Hungarica 19(3): 109131.

[35] Mikkola, K. (1972): Behavioural and electrophysiological responses of night-flying insects, especially Lepidoptera, to near-ultraviolet and visible light. - Ann. Zool. Fenn. 9: 225-254.

[36] Moore, D.S., McCabe, G.P., Craig, B.A. (2006) Introduction to the Basic Practice of Statistics. - New York, W.H. Freeman \& Co, $5^{\text {th }}$ edition.

[37] Moser, J.C., Reeve, J.D., Bento, J.M.S., Della Lucia, T.M.C., Cameron, R.S., Heck, N.M. (2004): Eye size and behaviour of day- and night-flying leafcutting ant alates. - Journal of Zoology (London) 264: 69-75.

[38] Nabli, H., Baily, W.C., Necibi, S. (1999): Beneficial insect attraction to light traps with different wavelengths. - Biological Control 16(2): 185-188.

[39] National Institute of Standards and Technololgy(2010): Comparing multiple proportions: The Marascuillo procedure. - NIST/SEMATECH e-Handbook of Statistical Methods, http://www.itl.nist.gov/div898/handbook/prc/section4/prc474.htm.

[40] Nowinszky, L., Ekk, I. (1996): Comparative study of Macrolepidoptera caught in light traps operating with normal and ultra-violet light waves (in Hungarian). Növényvédelem 32(11): 557-567.

[41] Odor, P., Iglói, L. (1987): An introduction to the sport's biometry (in Hungarian). - ÁISH Tudományos Tanácsának Kiadása, Budapest, 267.

[42] Pappas, L.G., Eaton, J.L. (1977): The internal ocellus of Manduca sexta and spectral sensitivity. - Journal of Insect Physiology 23(1-2): 1355-1358.

[43] Puskás, J., Nowinszky, L. (1994): Comparison of Macrolepidoptera data collected by normal and UV light traps at Bakony-highlands (in Hungarian). - Folia Musei HistoricoNaturalis Bakonyiensis. Zirc 13: 89-105.

[44] Rutowski, R.L., Gislén, L., Warrant, E.J. (2009): Visual acuity and sensitivity increase allometrically with body size in butterflies. - Arthropod Structure \& Development 38: 91100.

[45] Sifter, F. (1971): The use of the UV light trap for studying the flight of Curculio (Balaninus) elephas (in Hungarian). - Növényvédelem 7(3): 108-110. 
[46] Skuhravý, V., Skuhravá, M., Brewer, W. (1993): The saddle gall midge Haplodiposis marginata (Diptera: Cecidomyidae) in Czech Republic and Slovak Republic from 19711989. - Acta Soc. Zool. Bohem. 57: 117-137.

[47] Spaethe, J., Chittka, L. (2003): Interindividual variation of eye optics and single object resolution in bumblebees - The Journal of Experimental Biology 206: 3447-3453.

[48] Taylor, J.G., Deay, H.O. (1950): Electric lamps and traps in Corn Borer control. Agricultural Engineering 31(10): 513-505.

[49] Teel, P.D., VanCleave, H.W., Hollingsworth, J.P., Harstack, A.W. (1976): Spectral sensitivity of the Hickory Shuckworm to electromagnetic radiation. - Journal of Economic Entomology 69(1): 57-58.

[50] Theowald, B.R. (1963): Faunistische en fenologische waarnemingen met betrekking tot langpootmuggen (Diptera, Tipulidae). Fenologisch en faunistisch ondezoek over boomgardinsekten. Wageningen. - Versl. Landbounk. Onderz. 139: 185-202.

[51] van Langevelde, F., Ettema J.A., Donners M., Wallis DeVries, M.F., Groenendijk, D. (2011): Effect of spectral composition of artificial light on the attraction of moths. Biological Conservation. doi:10.1016/j.biocon.2011.06.004.

[52] Voigt, E., Vojnits, A. (1970): Observation of the species Eupoecilia ambiguella Hbn. and Lobesia botrana Den. et Schiff. by means of light traps (in Hungarian). - Növényvédelem 6(8): 352-357.

[53] Wallner, W.E., Humble, L.M., Levin, R.E., Baranchikov, Y.N., Cardé, R.T. (1995): Response of adult lymantriid moths to illumination devices in the Russian Far East. - J. Econ. Entomol. 88(2): 337-342.

[54] Yack, J.E., Johnson, S.E., Brown, S.G., Warrant, E.J. (2007): The eyes of Macrosoma sp. (Lepidoptera: Hedyloidea): A nocturnal butterfly with superposition optics. - Arthropod Structure \& Development 36: 11-22.

[55] Zollikofer, Ch.P.E., Wehner, R., Fukushi, T. (1995): Optical scaling in conspecific Cataglyphis ants. - The Journal of Experimental Biology 198: 1637-1646. 